\title{
The preservation effect of coronary collateral circulation on left ventricular function in chronic total occlusion and its association with the expression of vascular endothelial growth factor $\mathrm{A}$
}

\author{
Yuxiang Dai ${ }^{1, B-D}$, Shufu Chang ${ }^{1, B-D}$, Shen Wang ${ }^{2, B, C}$, Yi Shen ${ }^{3, B, C}$, Chenguang $\mathrm{Li}^{1, B, C}$, Zheyong Huang ${ }^{1, B}$, \\ Hao Lu ${ }^{1, B}$, Juying Qian ${ }^{1, B}$, Lei Ge Ge $^{1, B, E}$, Qibing Wang ${ }^{1, B}$, Feng Zhang ${ }^{1, B}$, Junbo Ge $e^{1, A, F}$ \\ ${ }^{1}$ Department of Cardiology, Fudan University Affiliated Zhongshan Hospital, Shanghai, China \\ 2 Department of Cardiology, Xinhua Hospital of Zhejiang Province, the Second Affiliated Hospital of Zhejiang Chinese Medical University, China \\ ${ }^{3}$ Department of Geratology, Fudan University Affiliated Zhongshan Hospital, Shanghai, China \\ A - research concept and design; $\mathrm{B}$ - collection and/or assembly of data; $\mathrm{C}$ - data analysis and interpretation; \\ $D$ - writing the article; $E$ - critical revision of the article; $F$ - final approval of the article
}

Address for correspondence

Junbo Ge

E-mail: guoronglang@yeah.net

Funding sources

This work was supported by the National Natural Science Foundation of China (grant No. 81300095).

Conflict of interest

None declared

Received on August 17, 2018

Reviewed on October 28, 2018

Accepted on February 18, 2019

Published online on April 27, 2020

Cite as

Dai Y, Chang S, Wang S, et al. The preservation effect of coronary collateral circulation on left ventricular function in chronic total occlusion and its association with the expression of vascular endothelial growth factor $A$. Adv Clin Exp Med. 2020;29(4):493-497.

doi:10.17219/acem/104535

DOI

10.17219/acem/104535

Copyright

Copyright by Author(s)

This is an article distributed under the terms of the

Creative Commons Attribution Non-Commercial License

(http://creativecommons.org/licenses/by-nc-nd/4.0/)

\begin{abstract}
Background. Patients with coronary chronic total occlusion (CTO) typically have collateralization of the distal vessel, and these collaterals can contribute to the relief of ischemia and anginal symptoms and to the preservation of ventricular function.
\end{abstract}

Objectives. To investigate the preservation effect of coronary collateral circulation on left ventricular (LV) function in coronary CTO, and to explore the potential mechanism behind the development of coronary collateral circulation.

Material and methods. A total of 102 consecutive patients with coronary CTO were divided into 2 groups: the left ventricular ejection fraction (LVEF)-preserved group (LVEF $\geq 50 \% ; n=46$ ) and the LVEF-decreased group (LVEF < 50\%; $n=56$ ). Clinical, angiographic and laboratory data was collected for all patients. The association between LVEF and coronary collateral circulation in coronary CTO patients was analyzed with multivariate logistic regression analysis, and the serum levels of VEGF-A and the mRNA expression levels of the VEGF-A gene were compared between different grades of coronary collateral circulation.

Results. Multivariate analysis revealed that Rentrop grades 2-3 and coexisting collateral pathways were independent predictors of LVEF preservation in coronary CTO patients. Patients with Rentrop grades $2-3$ had smaller left ventricular end diastolic diameters (LVDd) and left ventricular end systolic diameters (LVSd), and they had larger LVEFs than the patients with Rentrop grades 0 -1. Patients with Rentrop grades 2-3 also had higher serum levels of VEGF-A and higher mRNA expression levels of the VEGF-A gene in their peripheral blood mononuclear cells (PBMCs) than patients with Rentrop grades 0 -1. Patients with coexisting collateral pathways had higher serum levels of VEGF-A and higher mRNA expression levels of the VEGF-A gene in PBMCs than patients without coexisting collateral pathways.

Conclusions. Coronary collateral circulation is significantly associated with LVEF preservation, and VEGF-A might promote the formation of coronary collateral circulation.

Key words: chronic total occlusion, left ventricular ejection fraction, coronary collateral circulation, vascular endothelial growth factor $\mathrm{A}$ 


\section{Introduction}

Coronary chronic total occlusion (CTO) is defined as a complete (or nearly complete) occlusion of the coronary vessel with thrombolysis in myocardial infarction (TIMI) flow grade 0 or 1 lasting 3 months or longer. ${ }^{1,2} \mathrm{~Pa}$ tients with CTO typically have collateralization of the distal vessel, and these collaterals can contribute to the relief of ischemia and anginal symptoms and to the preservation of ventricular function. ${ }^{3,4}$

As one of the most important angiogenic factors, vascular endothelial growth factor (VEGF) may promote the development of collateral formation through its ability to maintain the vascular bed, stimulating proliferation/ migration of endothelial cells and increasing the permeability of blood vessels. ${ }^{5,6}$ In this study, the association between left ventricular ejection fraction (LVEF) and coronary collateral circulation in coronary CTO patients was analyzed with multivariate logistic regression analysis. The serum levels of VEGF-A and the mRNA expression levels of the VEGF-A gene were compared between different grades of coronary collateral circulation. The aim was to evaluate the preservation effect of coronary collateral circulation on left ventricular (LV) function and to explore the potential mechanism behind the development of coronary collateral circulation.

\section{Material and methods}

\section{Patients}

A total of 102 consecutive patients with coronary CTO from the Department of Cardiology at Fudan University Affiliated Zhongshan Hospital, Shanghai, China, were enrolled between January and April 2014. The inclusion criteria were: 1 ) age $\geq 18$ years; 2 ) symptomatic angina and/or a positive functional ischemia test; and 3) CTO in at least 1 major epicardial coronary artery detected with diagnostic coronary angiography. The exclusion criteria consisted of: 1) a previous coronary artery bypass graft (CABG); 2) a medical history of cardiogenic shock or cardiopulmonary resuscitation; or 3) an ST-segment elevation myocardial infarction (STEMI) during the previous $48 \mathrm{~h}$. Clinical, angiographic and laboratory data was collected for all patients. This study was approved by the ethics committee of Zhongshan Hospital (approval No. 2013006028) and all patients provided written informed consent.

\section{Angiography and grading of coronary collateral circulation}

All angiographies were performed with Axiom-Artis DTA (Siemens, Munich, Germany) or a Innova 2000 system (GE, Evansville, USA) via the radial artery or femoral artery approach. Angiographic results were analyzed using a GE centricity AI 1000-GE Mnet (v. 4.2.7.05). Coronary collateral circulation was graded according to the Rentrop scoring system $(0=$ no visible filling of any collateral vessels; 1 = filling of the small side branches; 2 = partial filling of the epicardial artery; 3 = complete filling of the epicardial artery). ${ }^{7}$ The grading of coronary collateral circulation was performed independently by 2 angiographers and a consensus was reached in the case of any disagreement.

\section{Measurement of serum VEGF-A levels}

For all patients, $10 \mathrm{~mL}$ of whole blood was collected in ethylenediaminetetraacetic acid (EDTA) tubes via peripheral veins immediately after angiography. The samples were then centrifuged at $1,500 \mathrm{~g}$ for $10 \mathrm{~min}$ at $20^{\circ} \mathrm{C}$. The supernatant was collected and serum levels of VEGF-A were measured with a human VEGF-A ELISA Kit (Invitrogen, Waltham, USA) according to the manufacturer's instructions.

\section{Measurement of mRNA expression levels of VEGF-A}

Peripheral blood mononuclear cells (PBMCs) were isolated using Ficoll density gradient (Biocoll; Biochrom, Berlin, Germany) centrifugation for $30 \mathrm{~min}$ at $500 \mathrm{~g}$. The interphase layer of PBMCs was washed in phosphate-buffered saline (PBS) and then centrifuged for $15 \mathrm{~min}$ at $200 \mathrm{~g}$. Total RNA was extracted from the PBMCs using Trizol (Invitrogen). Reverse transcriptase-polymerase chain reaction (RT-PCR) was used to evaluate mRNA expression levels of VEGF-A in the PBMCs. Total RNA $(1 \mu \mathrm{g})$ was reverse-transcribed into complementary deoxyribonucleic acid (cDNA) with a cDNA synthesis kit (SYBR Premix Ex Taq; Takara Bio Inc., Kusatsu, Japan). The cDNA was denatured at $95^{\circ} \mathrm{C}$ for $5 \mathrm{~min}$, then amplified for 40 cycles at $94^{\circ} \mathrm{C}$ for $15 \mathrm{~s}$ and at $60^{\circ} \mathrm{C}$ for $30 \mathrm{~s}$ in a Light Cycler (Roche Diagnostics, Rotkreuz, Switzerland). The relative quantification of the mRNA expression levels of $V E G F-A$ was performed with the $\triangle \triangle \mathrm{Ct}$ method, and GAPDH was used as the reference gene. The sense and antisense primers of $V E G F-A$ and GAPDH used in this study were as follows: $V E G F-A$ (sense: $5^{\prime}$-ACTTCTGGGCTGTTCTCG-3'; antisense: 5'-TCCTCTTCCTTCTCTTCTTCC-3') and GAPDH (sense: 5'-ACAGTCAGCCGCATCTTC-3'; antisense: 5'-CTCCGACCTTCACCTTCC-3').

\section{Statistical analysis}

Categorical variables are expressed as percentages, while continuous variables are expressed as mean \pm standard deviation (SD). Univariate analysis was performed with a $\chi^{2}$ test or Student's t-test. The variables in the univariate analysis with a p-value $<0.10$ were included in the multivariate analysis with a backward stepwise logistic regression model. Multivariate logistic regression analysis was 
then performed to identify the association between LVEF and coronary collateral circulation. The left ventricular end diastolic diameters (LVDd), left ventricular end systolic diameters (LVSd), LVEF, serum VEGF-A levels, and mRNA $V E G F-A$ expression levels were compared using Student's t-test. The IBM SPSS Statistics for Windows v. 19.0 software (IBM Corp., Armonk, USA) was employed to perform all statistical analyses. The significance level was set at $\mathrm{p}<0.05$.

\section{Results}

\section{Univariate analysis}

The 102 patients were divided into 2 groups according to LVEF: the LVEF-preserved group (LVEF $\geq 50 \%$; $n=46)$ and the LVEF-decreased group (LVEF < 50\%; $\mathrm{n}=56$ ). The characteristics of demography, medical history, biochemical parameters and angiography for the 2 groups are shown in Table 1 . Univariate analysis showed that prior myocardial infarction, creatinine level, Rentrop grade, and the status of coexisting collateral pathways were statistically significantly different between the LVEF-decreased group and the LVEF-preserved group (Table 1).

\section{Multivariate analysis}

Multivariate logistic regression analysis was performed in order to determine the association between LVEF and coronary collateral circulation, adjusting for diabetes mellitus, prior myocardial infarction and creatinine level. According to the results of multivariate analysis, Rentrop grades 2-3 and coexisting collateral pathways were independent predictors for LVEF preservation in coronary CTO patients (Table 2).

\section{LV function of different Rentrop grades}

Echocardiography parameters showed that patients with Rentrop grades $2-3$ had smaller LVDds $(46.83 \pm 2.86 \mathrm{~mm}$ vs $50.08 \pm 3.27 \mathrm{~mm} ; \mathrm{p}=0.021)$ and LVSds $(32.79 \pm 2.81 \mathrm{~mm}$ vs $36.12 \pm 3.22 \mathrm{~mm}: \mathrm{p}=0.019)$, and larger LVEFs $(53.46 \pm 5.18 \%$ vs $48.35 \pm 4.29 \%$; $\mathrm{p}=0.020)$ than patients with Rentrop grades $0-1$. These results suggest that high Rentrop grades are associated with proper LV functioning.

\section{Serum VEGF-A levels and mRNA expression levels of the VEGF-A gene}

Patients with Rentrop grades $2-3$ had higher serum levels of VEGF-A $(141.92 \pm 46.31 \mathrm{pg} / \mathrm{mL}$ vs $76.34 \pm 32.75 \mathrm{pg} / \mathrm{mL}$; $\mathrm{p}=0.028)$ and higher $\mathrm{mRNA}$ expression levels of the $V E G F-A$ gene in their peripheral blood mononuclear cells $(0.93 \pm 0.25$ vs $0.62 \pm 0.19$; $\mathrm{p}=0.001)$ than patients with Rentrop grades $0-1$. Patients with coexisting collateral pathways
Table 1. Characteristics of the demography, medical history, biochemical parameters, and angiography in the LVEF-decreased group and the LVEFpreserved group

\begin{tabular}{|c|c|c|c|}
\hline Parameter & $\begin{array}{l}\text { LVEF-preserved } \\
\text { group }(n=46)\end{array}$ & $\begin{array}{l}\text { LVEF-decreased } \\
\text { group }(n=56)\end{array}$ & $p$-value \\
\hline \multicolumn{4}{|c|}{ Demographics } \\
\hline Age [years] & $60.4 \pm 8.9$ & $59.4 \pm 9.9$ & 0.665 \\
\hline Male [n/\%] & $35 / 76.1$ & $38 / 67.9$ & 0.387 \\
\hline $\begin{array}{l}\text { Body mass index } \\
{\left[\mathrm{kg} / \mathrm{m}^{2}\right]}\end{array}$ & $26.6 \pm 1.9$ & $26.6 \pm 1.7$ & 0.734 \\
\hline \multicolumn{4}{|c|}{ Medical history } \\
\hline $\begin{array}{l}\text { Diabetes mellitus } \\
{[\mathrm{n} / \%]}\end{array}$ & $12 / 26.1$ & $25 / 44.6$ & 0.054 \\
\hline $\begin{array}{l}\text { Cigarette smoking } \\
{[\mathrm{n} / \%]}\end{array}$ & $30 / 65.2$ & $35 / 62.5$ & 0.838 \\
\hline $\begin{array}{l}\text { Hypertension } \\
{[\mathrm{n} / \%]}\end{array}$ & $24 / 52.2$ & $33 / 58.9$ & 0.551 \\
\hline $\begin{array}{l}\text { Family history } \\
\text { of CAD [n/\%] }\end{array}$ & $12 / 26.1$ & $13 / 23.2$ & 0.819 \\
\hline $\begin{array}{l}\text { Hyperlipidemia } \\
\text { [n/\%] }\end{array}$ & $22 / 47.8$ & $29 / 51.8$ & 0.842 \\
\hline $\begin{array}{l}\text { Peripheral vascular } \\
\text { disease }[\mathrm{n} / \%]\end{array}$ & $8 / 17.4$ & $12 / 21.4$ & 0.803 \\
\hline $\begin{array}{l}\text { Prior myocardial } \\
\text { infarction [n/\%] }\end{array}$ & $8 / 17.4$ & $21 / 37.5$ & 0.029 \\
\hline $\begin{array}{l}\text { Cerebrovascular } \\
\text { disease }[\mathrm{n} / \%]\end{array}$ & $2 / 4.4$ & $2 / 3.6$ & 1.000 \\
\hline Prior PCI [n/\%] & $8 / 17.4$ & $7 / 12.5$ & 0.579 \\
\hline Prior CABG [n/\%] & $5 / 10.9$ & $6 / 10.7$ & 1.000 \\
\hline \multicolumn{4}{|c|}{ Biochemical parameters } \\
\hline Troponin I [ng/mL] & $0.01 \pm 0.004$ & $0.01 \pm 0.005$ & 0.860 \\
\hline Creatinine $[\mathrm{mg} / \mathrm{dL}]$ & $73.8 \pm 23.1$ & $82.9 \pm 22.4$ & 0.048 \\
\hline $\begin{array}{l}\text { Cholesterol } \\
{[\mathrm{mmol} / \mathrm{L}]}\end{array}$ & $5.6 \pm 0.8$ & $5.5 \pm 0.9$ & 0.401 \\
\hline LDL-C [mmol/L] & $3.6 \pm 0.7$ & $3.6 \pm 0.6$ & 0.858 \\
\hline $\mathrm{HbA}_{1} \mathrm{C}[\%]$ & $6.2 \pm 0.4$ & $6.2 \pm 0.5$ & 0.350 \\
\hline \multicolumn{4}{|c|}{ Angiographic findings } \\
\hline $\begin{array}{l}\text { Collateral circulation } \\
\text { (Rentrop } 2-3 \text { ) [n/\%] }\end{array}$ & $37 / 80.4$ & $32 / 57.1$ & 0.019 \\
\hline $\begin{array}{l}\text { Coexisting collateral } \\
\text { pathways }\end{array}$ & $17 / 36.9$ & 10/17.9 & 0.042 \\
\hline
\end{tabular}

CAD - coronary artery disease; CABG - coronary artery bypass grafting; LDL-C - low-density-lipoprotein cholesterol; LVEF - left ventricular ejection fraction; $\mathrm{PCl}$ - percutaneous coronary intervention.

Table 2. Association between LVEF and coronary collateral circulation

\begin{tabular}{|l|c|c|c|}
\multicolumn{1}{|c|}{ Parameter } & OR & $95 \% \mathrm{Cl}$ & p-value \\
\hline Diabetes mellitus & 0.298 & $0.105-0.843$ & 0.021 \\
\hline Prior myocardial infarction & 0.374 & $0.126-1.091$ & 0.063 \\
\hline Creatinine [mg/dL] & 0.526 & $0.402-1.271$ & 0.184 \\
\hline Collateral grading & 3.971 & $1.472-10.634$ & 0.006 \\
\hline Coexisting collateral pathways & 1.842 & $1.016-4.095$ & 0.043 \\
\hline
\end{tabular}

LVEF - left ventricular ejection fraction; OR - odds ratio; 95\% Cl - 95\% confidence interval. 
had higher serum levels of VEGF-A (138.41 $\pm 45.76 \mathrm{pg} / \mathrm{mL}$ vs $83.68 \pm 33.29 \mathrm{pg} / \mathrm{mL} ; \mathrm{p}=0.035)$ and higher mRNA expression levels of the VEGF-A gene in their PBMCs $(0.88 \pm 0.23$ vs $0.64 \pm 0.20 ; \mathrm{p}<0.001)$ than patients without coexisting collateral pathways. These results suggest that VEGF-A is associated with the development of coronary collateral circulation.

\section{Discussion}

Collateral circulation, which has the ability to provide blood flow to an area whose original supply vessel is obstructed, can be observed in almost all coronary CTOs. ${ }^{8,9}$ Therefore, collateral blood supply to an ischemic area may maintain metabolic supply and prevent myocardial necrosis. ${ }^{4,10}$ The prognosis is mainly determined by the extent of the myocardial infarction or ischemia in patients suffering from coronary CTOs. Coronary collateral circulation plays a key role in decreasing the size of a myocardial infarct or ischemia. ${ }^{11,12}$ Previous reports have demonstrated that better coronary collateral circulation is associated with smaller infarcts, less ventricular aneurysm formation, improved ventricular function, fewer future cardiovascular events, and improved survival. ${ }^{13-15}$ In our study, 46 of the 102 patients with coronary CTO had preserved LVEF, and they had higher percentages of better-developed coronary collateral circulation (Rentrop grades 2-3) and multiple coexisting collateral pathways. Coexisting collateral pathways may help the region supplied by the obstructed vessel to receive more blood supply, may help to restore more perfusion and may help to preserve systolic function. Multivariate analysis also revealed that Rentrop grades $2-3$ and coexisting collateral pathways are independent predictors for LVEF preservation in coronary CTO patients.

The growth of collateral vessels includes the proliferation of capillaries in the ischemic area (angiogenesis) and the maturation of pre-existing collateral vessels (arteriogenesis). ${ }^{16,17}$ Angiogenesis is the sprouting of new capillaries from existing vascular structures; it is triggered by endothelial cell migration and proliferation. ${ }^{4,9,17}$ Vascular endothelial growth factor possesses multiple functions, such as inducing the migration and proliferation of endothelial cells, enhancing vascular permeability and modulating thrombogenicity, all of which have been confirmed experimentally in vivo and in vitro. ${ }^{18,19}$ Vascular endothelial growth factor is secreted by a variety of cells, including aortic smooth muscle cells, macrophages, myocytes, lymphocytes, neutrophils, and platelets. ${ }^{20}$ In the case of severe coronary stenosis or CTO, the secretion of VEGF is upregulated because of ischemia and hypoxia. ${ }^{21,22}$ The endothelial cells then detach, migrate, proliferate, and finally form a new vessel. ${ }^{23}$ In this study, serum VEGF-A levels and mRNA expression levels of the VEGF-A gene in PBMCs were measured to determine their association with coronary collateral circulation, and the results showed that well-developed coronary collateral circulation was associated with higher levels of serum VEGF-A and mRNA expression of the VEGF-A gene. This is consistent with previous findings that the formation of collateral circulation is regulated by VEGF. ${ }^{21,24}$

Elevated expression of VEGF is important for the establishment of coronary collateral circulation in CTOs. Furthermore, elevated VEGF expression is conducive to the survival, homing and directional differentiation of endothelial progenitor cells and myocardial repair. Thus, VEGF is an important potential therapeutic target for promoting collateral growth in the treatment of CTOs with no suitable revascularization option. Although animal experiments have confirmed that collateral circulation improves greatly after delivering angiogenic growth factors, ${ }^{23,25}$ further evidence is needed in coronary CTO patients.

\section{Conclusions}

Coronary collateral circulation was statistically significantly correlated with LVEF preservation, and VEGF-A might promote the formation of coronary collateral circulation.

\section{ORCID iDs}

Yuxiang Dai (D) https://orcid.org/0000-0002-2232-9136 Shufu Chang (D) https://orcid.org/0000-0001-5672-2158 Shen Wang (D) https://orcid.org/0000-0001-5336-4324 Yi Shen (i) https://orcid.org/0000-0001-6903-7643 Chenguang Li (D) https://orcid.org/0000-0001-9708-1289 Zheyong Huang (D) https://orcid.org/0000-0003-4538-4848 Hao Lu (1) https://orcid.org/0000-0003-3401-135X Juying Qian (D) https://orcid.org/0000-0002-6155-6577 Lei Ge (D) https://orcid.org/0000-0003-2704-7100

Qibing Wang (D) https://orcid.org/0000-0002-8033-1840

Feng Zhang (D) https://orcid.org/0000-0003-1405-2293

Junbo Ge (D) https://orcid.org/0000-0003-1030-7009

\section{References}

1. Shah PB. Management of coronary chronic total occlusion. Circulation. 2011;123(16):1780-1784.

2. Lee CK, Chen YH, Lin MS, et al. Retrograde approach is as effective and safe as antegrade approach in contemporary percutaneous coronary intervention for chronic total occlusion: A Taiwan singlecenter registry study. Acta Cardiol Sin. 2017;33(1):20-27.

3. Seiler C. Assessment and impact of the human coronary collateral circulation on myocardial ischemia and outcome. Circ Cardiovasc Interv. 2013;6(6):719-728.

4. Seiler C, Stoller M, Pitt B, Meier P. The human coronary collateral circulation: Development and clinical importance. Eur Heart J. 2013;34(34): 2674-2682.

5. Bernatchez PN, Soker S, Sirois MG. Vascular endothelial growth factor effect on endothelial cell proliferation, migration, and plateletactivating factor synthesis is Flk-1-dependent. J Biol Chem. 1999; 274(43):31047-31054.

6. Dulak J, Jozkowicz A, Frick M, et al. Vascular endothelial growth factor: Angiogenesis, atherogenesis or both? J Am Coll Cardiol. 2001; 38(7):2137-2138.

7. Rentrop KP, Cohen M, Blanke H, Phillips RA. Changes in collateral channel filling immediately after controlled coronary artery occlusion by an angioplasty balloon in human subjects. J Am Coll Cardiol. 1985;5(3):587-592. 
8. Schaper W. Collateral circulation: Past and present. Basic Res Cardiol. 2009;104(1):5-21.

9. Seiler C. The human coronary collateral circulation. Eur J Clin Invest. 2010;40(5):465-476.

10. Teunissen PF, Horrevoets AJ, van Royen N. The coronary collateral circulation: Genetic and environmental determinants in experimental models and humans. J Mol Cell Cardiol. 2012;52(4):897-904.

11. Karrowni W, El Accaoui RN, Chatterjee K. Coronary collateral circulation: Its relevance. Catheter Cardiovasc Interv. 2013;82(6):915-928.

12. Małek $Ł A$, Śpiewak M, Kłopotowski M, Marczak M, Witkowski A Combined analysis of myocardial function, viability, and stress perfusion in patients with chronic total occlusion in relation to collateral flow. Kardiol Pol. 2015;73(10):909-915.

13. McEntegart MB, Badar AA, Ahmad FA, et al. The collateral circulation of coronary chronic total occlusions. Eurolntervention. 2016;11(14): e1596-e1603.

14. Choi JH, Chang SA, Choi JO, et al. Frequency of myocardial infarction and its relationship to angiographic collateral flow in territories supplied by chronically occluded coronary arteries. Circulation. 2013; 127(6):703-709.

15. Meier P, Hemingway H, Lansky AJ, Knapp G, Pitt B, Seiler C. The impact of the coronary collateral circulation on mortality: A meta-analysis. Eur Heart J. 2012;33(5):614-621.

16. Chilian WM, Penn MS, Pung YF, et al. Coronary collateral growth: Back to the future. J Mol Cell Cardiol. 2012;52(4):905-911.

17. Fujita $M$, Tambara K. Recent insights into human coronary collateral development. Heart. 2004;90(3):246-250.
18. Gerhardt H. VEGF and endothelial guidance in angiogenic sprouting. Organogenesis. 2008;4(4):241-246.

19. Cai J, Jiang WG, Ahmed A, Boulton M. Vascular endothelial growth factor-induced endothelial cell proliferation is regulated by interaction between VEGFR-2, SH-PTP1 and eNOS. Microvasc Res. 2006;71(1): 20-31.

20. Hamamichi Y, Ichida F, Yu X, et al. Neutrophils and mononuclear cells express vascular endothelial growth factor in acute Kawasaki disease: Its possible role in progression of coronary artery lesions. Pediatr Res. 2001;49(1):74-80.

21. Toyota E, Warltier DC, Brock T, et al. Vascular endothelial growth factor is required for coronary collateral growth in the rat. Circulation. 2005;112(14):2108-2113.

22. Clayton JA, Chalothorn D, Faber JE. Vascular endothelial growth factor-A specifies formation of native collaterals and regulates collateral growth in ischemia. Circ Res. 2008;103(9):1027-1036.

23. Schirmer SH, van Nooijen FC, Piek JJ, van Royen N. Stimulation of collateral artery growth: Travelling further down the road to clinical application. Heart. 2009;95(3):191-197.

24. Lucitti JL, Mackey JK, Morrison JC, Haigh JJ, Adams RH, Faber JE. Formation of the collateral circulation is regulated by vascular endothelial growth factor-A and a disintegrin and metalloprotease family members 10 and 17. Circ Res. 2012;111(12):1539-1550.

25. Degen A, Millenaar D, Schirmer SH. Therapeutic approaches in the stimulation of the coronary collateral circulation. Curr Cardiol Rev. 2014;10(1):65-72. 